\title{
У EVIDENTIAL STRATEGIES IN NYAMWEZI
}

\author{
Ponsiano Sawaka Kanijo \\ Mkwawa University College of Education
}

\begin{abstract}
This paper provides an overview of evidential strategies in Nyamwezi. Nyamwezi, like many other African languages, does not have specific grammatical categories which indicate evidentiality, but evidentiality can be expressed (i) through tense and aspect constructions and (ii) through lexical verbs (particularly verbs of saying and verbs of perception) and epistemic expressions. These evidential strategies differ from each other based on the information source, that is, on the source of knowledge expressed in a proposition, and on the speaker's attitude and view concerning that knowledge.
\end{abstract}

\section{INTRODUCTION}

The main goal of this paper is to provide a general description of strategies employed to denote evidentiality in Nyamwezi (F22, ISO 639-3: nym). ${ }^{1}$ These strategies are of two types. The first type includes evidential strategies expressed by tense and aspect constructions and the second type includes strategies expressed by lexical items. With regard to the former, the paper focuses on three tense and aspect constructions: the Hodiernal Past $\left(-a^{-}-\ldots-a g-\ldots-a\right)$, the Imperfective aspect $\left(-l_{I I-}\right)$, and the stative construction (-ø-...-ile), ${ }^{2}$ which mainly occurs with inchoative verbs to denote evidential meanings. The evidential meanings come to light especially in contexts where the interpretations/translations in English are the same. In (1) below, to say that 'They (for example, the mangoes) are rotten', one may either use the Hodiernal Past (1a) or the stative construction (1b).

1 The first version of this paper was presented at the conference "The semantics of verbal morphology in underdescribed languages", held in June 2017 at the University of Gothenburg; see the Introduction to this volume. I thank all those who gave feedback during the presentation. I also thank Laura Downing, Malin Petzell, Thera Crane, Lotta Aunio, and two anonymous reviewers for their insightful comments and suggestions on an earlier version of this paper. I remain solely responsible for the views expressed.

2 In other studies on tense and aspect in Bantu languages (see, eg. Nurse 2008) and in the grammatical sketch of Nyamwezi by Maganga and Schadeberg (1992), the -ø-...-ile construction is analysed as Perfect(ive)/Retrospective aspect. However, in this study, -ø-...-ile, as I have argued in my previous works (Kanijo 2019a; 2019b), can best be analysed as a stative construction. This is because it commonly occurs with inchoative (or change-of-state) verbs to express a present state resulting from a past/prior event. The construction is generally unacceptable with noninchoative verbs, except with motion verbs with a directional interpretation and a goal such as -ja 'go (somewhere)'. Analyses of -ø-...-ile as stative constructions in other Bantu languages can be found in Totela (K41, ISO 639-3: ttl) (see Crane 2011; 2012; 2013) and Fwe (K402, ISO 639-3: fwe) (see Gunnink 2018).

Volume 8(3) (2020), pp. 81-98

DOI $10.23993 /$ store. 71147

Licensed under Creative Commons 4.0 (CC BY-NC-SA 4.0) license. 
(1a) gaaßólaga

gá-á- $\beta$ ol-ag-a

6SM-PST-be(come)_rotten-HOD_PST-FV

'They (for example, the mangoes) are rotten.'

(1b) gaßólilé

gá-o-ßol-íle

6SM-PST-be(come)_rotten-STAT

'They (for example, the mangoes) are rotten.'

Similarly, one may use either the Imperfective aspect or the stative construction to refer to an event which is generally conceived of as being in progress at the time of speaking. This is exemplified in (2a) and (2b), respectively.
(2a) alıja
kwiigolilv
a-lıI-j-a kv-igólílv
SM1-IPFV-go-FV LOC.17-market

'S/he is going to the market.'
(2b) aziilé kwígolílo
a-o-j-íle ko-igólílo
SM1-PST-go-STAT LOC.17-market

'S/he is going to the market.'

In this paper, I argue that in contexts such as those in (1) and (2) above, where the interpretations/ translations of two different constructions into English are the same, the difference in meaning can be determined using insights from evidentiality. That is, the choice of one form over the other depends on (i) the source of evidence the speaker uses to justify the truth of the expressed proposition, and (ii) the speaker's attitude towards the validity of the evidence. In addition to these three tense and aspect constructions, the paper also describes some of the lexical items that may serve the purpose of indicating evidentiality.

Before proceeding to the analysis, in Section 2 I give a brief typological introduction to the definitions and types of evidentiality. In Section 3, I present different ways of encoding evidentiality. In Section 4, I give some linguistic information about Nyamwezi and describe the verbs for which the tense and aspect constructions discussed in this paper have identical translations in English. In Section 5, I will discuss the strategies for denoting evidential meanings in Nyamwezi, starting first with those denoted by the three tense and aspect constructions described above, then moving to those evidential meanings which are lexically represented. The paper concludes in Section 6 with a summary of the major points.

\section{DEFINITIONS AND TYPES OF EVIDENTIALITY}

The term "evidentiality" is broadly defined as the linguistic means of encoding the speaker's source of information for a given statement (Chafe \& Nichols 1986). The source of information can be that the speaker saw the event happen, or heard it, or was told about it by someone else. Sometimes the speaker's source of information can be his/her own experience of a particular phenomenon. Based on the source of information, there are different types of evidentiality systems which vary in terms of the number of information sources encoded. The simplest 
and most straightforward evidentiality system has just two choices; more complicated ones involve up to six (or possibly even more) choices. Two-term systems cover FIRSTHAND (direct/ eyewitness) and NON-FIRSTHAND (indirect/non-eyewitness) evidence. Languages with two-term systems contrast information acquired through vision, hearing, or other senses, and information acquired through inference and verbal reports.

Evidential systems providing three choices distinguish FIRSTHAND, INFERRED, and REPORTED evidence, INFERRED and REPORTED being sub-categories of non-firsthand. By definition, FIRSTHAND evidence, as stated above, refers to information acquired by seeing, or by any kind of sensory perception. Inferred evidence refers to 'inference', drawn on the basis of visible/ tangible information, or direct physical evidence, or based on the speaker's general knowledge and experience. Lastly, REPORTED evidence refers to information obtained from someone else (second hand/folklore). These types of evidentiality are briefly summarized in (3) below.

(3) Types of evidence (Willett 1988)

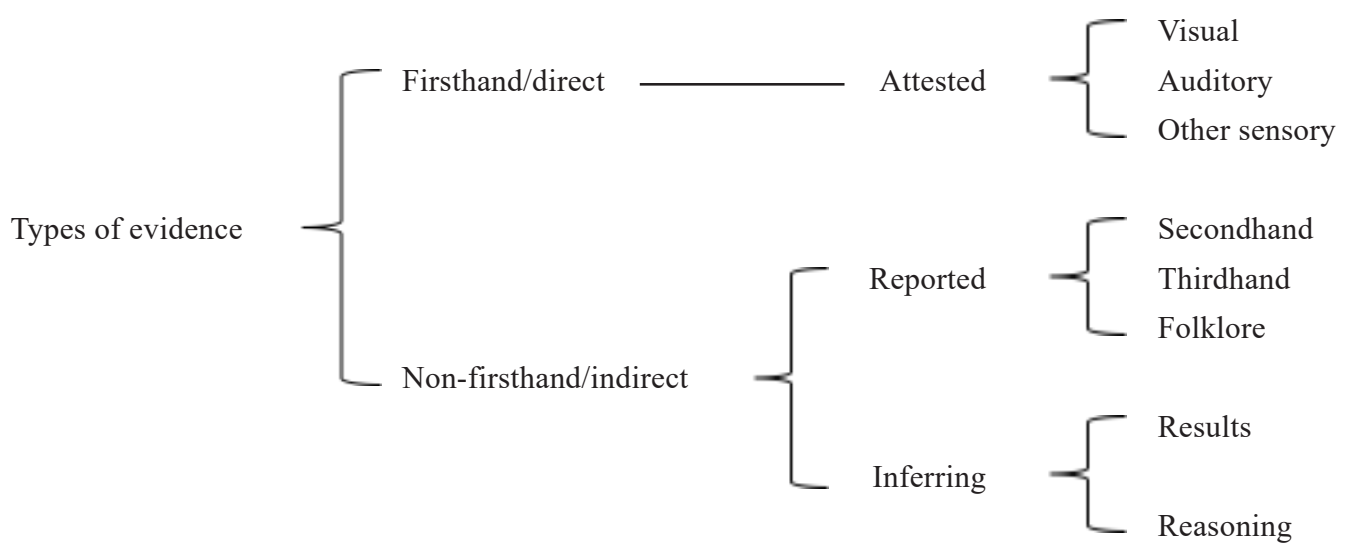

It is common cross-linguistically for evidential markers to serve other purposes, such as indicating the speaker's degree of confidence in the statement (Leiss 2012: 57). ${ }^{3}$ For example, direct evidential markers (those in which the evidence is based on sensory input such as visual or auditory information) usually serve to indicate that the speaker is certain about the event stated because $\mathrm{s} / \mathrm{he}$ witnessed it, while indirect evidential markers (those in which the evidence is based on reported speech and inferences) indicate that the speaker is uncertain about the statement (Willett 1988). Thus, Chafe (1986: 262) conceives evidentiality as a category which is not only restricted to indicating the source of the information in the proposition, but also "involve[s] attitudes towards the knowledge". Following Chafe (1986), evidentiality in this study is defined as a grammatical category which indicates both the source of information for the proposition expressed, and the speaker's attitude toward the factuality of that proposition.

\section{THE ENCODING OF EVIDENTIALITY}

All languages have some means of indicating evidentiality. Some languages (mostly indigenous languages of the Americas) have a specific grammatical category (that is, affixes, clitics, or particles) which indicates evidentiality. For example, in Cherokee (an Iroquoian language), the suffix

3 This role is indicated by epistemic modality in many languages. 
$-n i$ (exemplified in (4a)) is used if the speaker perceived the action or state described by the verb with one of the senses, while $-e ? i$, in (4b), covers information acquired in some other way.

(4) Cherokee (ISO 639-3: chr; Aikhenvald 2004: 26-27)
a. wesa $u$-tlis-九?i
cat it-run-FIRSTH.PST
'A cat ran.' (I saw it running)
b. u-wonis-e?i
he-speak.NON.FIRSTH.PST
'He spoke.' (someone told me)

In languages which incorporate evidentiality as a grammatical category (like Cherokee above), evidentiality is often differentiated from tense, aspect, and epistemic modality. Tense, aspect, and mood (TAM) concern the relationships of events in time and reality, while evidentiality is a category whose primary function is that of indicating the source of the information. However, not every language has a dedicated affix or clitic which indicates the evidential source. In some languages in the world, evidentiality marking is fused with other categories, mostly tense and aspect constructions. As discussed in Aikhenvald (2003; 2004), grammatical categories such as the perfect, resultative, and past tenses can each acquire a secondary evidential-like meaning which is often similar to that of the non-firsthand evidential. ${ }^{4}$ Comrie (1976) provides a plausible explanation for the semantic connection between perfect aspect and non-firsthand (inferential) evidentials. Comrie (1976: 110) states that "the semantic similarity [...] between perfect and inferential lies in the fact that both categories present an event not itself, but via results". In other words, in both categories, an inference is made based on some traces or results of a previous action or state. For example, in Georgian, the perfect aspect can be employed to talk about a past event which the speaker did not himself witness but which he assumes took place on the basis of some present result, as shown in (5).

(5) Georgian (ISO 639-3: kat; Hewitt 1995, as cited in Aikhenvald 2004: 113)

$$
\begin{aligned}
& \text { varken-s ianvr-is rva-sp'irvel-ad (Ø-)u-c'am-eb-i-a šušanik'-i } \\
& \text { Varsken-DAT January-GEN 8-DAT first-ADV (he-)OV-torture-TS-PERF-her Shushanik'-NOM }
\end{aligned}
$$

Most African languages are similar to Georgian (exemplified above), in which evidentiality is expressed through tense and aspect constructions. For example, Luwo (ISO 639-3: 1wo; see Storch 2006; 2018) and Shilluk (ISO 639-3: shk; see Miller \& Gilley 2007) have a non-firsthand evidential expressed through perfect aspect marking. Sukuma (F21, ISO 639-3: suk), a language closely related to Nyamwezi, distinguishes between eyewitness and non-eyewitness evidentials (see Nurse 2008: 166). The contrast, as in Luwo and Shilluk, is expressed with the tense and aspect constructions, especially the perfect(ive) aspect.

Ikoma/Nata/Isenye (JE45, ISO 639-3: ntk; Roth 2018) and Nzadi (B865, ISO 639-3: nzd; Crane, Hyman \& Tukumu 2011) have a kind of evidentiality system which is similar to that of Nyamwezi (discussed in the present study). In these languages, the evidential meanings come to

4 The tendency for the perfect aspect, past tense, and other categories such as passive and conditional mood to encode evidentiality is referred to as an "evidentiality strategy" in Aikhenvald (2003; 2004). 
light when two tense or aspect constructions have the same temporal interpretations in English. For example, Ikoma/Nata/Isenye, distinguishes between eyewitness evidentials, marked by the Perfect aspect ( $-k a ́-)$, and non-eyewitness evidentials, marked by the Perfective aspect (-iri). This is exemplified in (6a) and (6b), respectively (glosses adapted).

(6) Ikoma/Nata/Isenye (JE45, ISO 639-3: ntk; Roth 2018: 89)

Context: A child is taking a nap in the bedroom of a house.

a. $a-\boldsymbol{k} \dot{a}-\beta o o k-a$ 1SM-PERF-wake_up-FV

'S/he is waking up/has just woken up.'

Further context: Speaker is in the same room and can see the child.

b. n-a-ßook-iri

FOC-1SM-wake_up-PFV

'S/he is waking up/has just woken up.'

Further context: Speaker is outside the house and cannot see or hear the child.

Nzadi, like Ikoma/Nata/Isenye, distinguishes between eyewitness and non-eyewitness evidentials (see Crane, Hyman \& Tukumu 2011). ${ }^{5}$ The eyewitness evidential is marked by the first type of present tense (e-PRESENT), as shown in (7a) below, and the non-eyewitness evidential by the second type (a-PRESENT), as in (7b). Eyewitness evidentiality is used when the speaker is certain that the situation is occurring, while non-eyewitness evidentiality is used when the speaker considers the event to be uncertain.

(7) Nzadi (B865, ISO 639-3: nzd; Crane, Hyman \& Tukumu 2011: 127)

a. bo ép

'They are sleeping.'

Context: The speaker sees them.

b. bo a pó tós

'They are sleeping.'

Context: The speaker doesn't see them.

In those languages in which evidentiality occurs neither as a grammatical category nor in the form of various kinds of bounded affixes or clitics, evidentiality is periphrastically expressed through lexical items. For example, in Beya Lega (D25, ISO 639-3: lgm; see Botne 1997; 2003a: 448-449), there are two sentence level adverbial/epistemic elements which indicate evidentiality: ampú, which indicates the factuality of the assertion, as shown in (8a), and $a m b u$, which indicates doubt in the assertion, as in (8b). The evidential ampú indicates that the proposition expressed is based on robust or cogent evidence (direct sensory evidence), whereas $a ́ m b u$ indicates that the proposition expressed is based on secondhand knowledge.

5 Note that these types of evidentiality are described as epistemic rather than evidential in this study. 
(8) Beya Lega (D25, ISO 639-3: lgm; Botne 2003a: 448-449)

a. ampú Zuúla nú Muké ú bekilé isaga lyá Pịla

'(I know that) it was Zuula and Muke who took Pila's axe.'

b. ámbu Zuúla nú Muké ú bekilé isaga lyá Pịla

'(it appears that) it was Zuula and Muke who took Pila's axe.'

Evidentiality in African languages in general, and in Bantu languages in particular, remains understudied. Much more work needs to be done in this area, especially on semantics and pragmatics, given that this phenomenon in these languages is mostly expressed through non-evidential markers (such as tense, aspect and mood) and through various lexical items. In the next section, after presenting some linguistic information about Nyamwezi, I discuss the evidential meanings expressed by both tense and aspect constructions and by lexical items in this language.

\section{NYAMWEZI}

Nyamwezi is a Bantu language spoken by 796,339 speakers in rural and urban areas of Tabora, Tanzania (Rugemalira et al. 2009: 114). Nyamwezi is classified as F22. Other F languages which share linguistic features with Nyamwezi are Sukuma (F21, ISO 639-3: suk), Sumbwa (F23, ISO 639-3: suw), Kimbu (F24, ISO 639-3: kiv), and Bungu (F25, ISO 639-3: wun) (see Guthrie 19671971). Apart from Maganga and Schadeberg's (1992) sketch of Nyamwezi grammar, not very much has been documented about other grammatical features of this language (Kanijo 2019a). The morphological structure of the verb in Nyamwezi, shown in (9) below (recreated from Maganga \& Schadeberg 1992), is similar to that of other Bantu languages. A verb contains many grammatical markers, including subject and object markers (abbreviated as SM and oM, respectively), infinitive (INF), negative (NEG), tense, aspect, and mood (TAM), itive (IT), and many derivational markers, commonly known as verbal extensions (Ext.). Verbal extensions typically denote applicative, causative, reciprocal, passive, and so forth.

(9) The structure of verb forms

$$
\mathrm{SM}+\mathrm{NEG}+\mathrm{TAM}+\mathrm{IT}+\mathrm{OM} / \mathrm{INF}+\text { Root }+ \text { Ext. }+\mathrm{TAM}+\mathrm{TAM} / \mathrm{FV}+\text { Post-final }
$$

The tense, aspect, and mood marking morphemes, as shown in the verbal structure above, occupy three different positions, that is, the pre-root, the post-root, and the final vowel slot. Evidentiality in this language (as in other Bantu languages and many other African languages; see de Haan 2013) does not constitute a part of the verbal paradigm, but, as already stated, can be expressed through tense and aspect constructions. Before embarking on the issue of evidentiality, it is necessary to provide a description of verb classes, as the meanings of the tense and aspect constructions tend to vary depending on the semantics of the verbs.

For the purposes of this study, I assume two main classes of Nyamwezi verbs, INCHOATIVES and NON-INCHOATIVES, following Botne and Kershner (2000). ${ }^{6}$ Inchoative verbs encode a change-of-state or condition, as well as a result state (a state that results from a past changeof-state). Examples include - $\beta$ ola 'be(come) rotten', -faá 'die', -ikala 'sit/be seated', -gwa 'fall down', -saata 'be sick', and -moonda 'be soft', which in Vendler's (1967) analysis are referred

6 See also Crane \& Fleisch (2019). 
to as achievements (they describe the moment at which there is a transition to a result state), while in Botne (2003b), they are referred to as resultative achievements (they lack an accompanying process (a coming-to-be phase) before the punctual change-of-state). In Nyamwezi, inchoatives also include verbs such as -zwaala 'wear, dress (oneself)', -chißá 'block way/hole', $-s e \beta a$ 'be(come) hot', and -gIna 'be(come) fat', which lexicalize the process leading up to the result state. Some of these verbs, such as -zwaala 'wear, dress (oneself)' and -chißá 'block way/hole', are interpreted as accomplishments in Vendler's (1967) analysis, while others, such as -se $\beta a$ 'be(come) hot' and -gina 'be(come) fat', are degree achievements in neo-Vendlerian studies such as that of Dowty (1979), or transitional achievements in Botne's (2003b) analysis (as they encode both a coming-to-be phase and a result state phase).

In contrast to inchoatives, non-inchoatives include verbs that do not encode a change-ofstate and lack a result state, such as -lumá 'bite', -zugá 'cook', -lila 'cry', -luusa 'kick', -Imbá 'sing', -ishiná 'play, dance', -ßoná 'see', and -igwá 'hear'. In Vendler's (1967) terms, some of these verbs, such as -Imbá 'sing', can be described as activities and some, such as -ßoná 'see', as states. ${ }^{7}$ Non-inchoative verbs that include motion verbs with a directional interpretation and a goal, such as -ja 'go (somewhere)', -peela 'run (to something)', -shooka 'return (reverse, move backwards)', and -iza 'come (back towards a particular point)', behave somewhat differently from other non-inchoatives. These are the only verbs among non-inchoatives which can occur with the stative construction (see more in Section 5.1.2). For this reason, I treat them separately in this study. These verbs will be referred to as DIRECTIONALS.

Inchoative verbs and directionals play a central role in this study. These verbs, when occurring with the Hodiernal Past or Imperfective aspect, have the same kind of interpretation as that denoted by the stative construction. This is exemplified in (10) and (11) below, repeated from (1) and (2), respectively.

(10a) gaaßólaga gá-á- $\beta$ ol-ag-a 6SM-PST-be(come)_rotten-HOD_PST-FV

'They (for example, the mangoes) are rotten.'

(10b) gaßólilé

gá-o-ßol-íle

6SM-PST-be(come)_rotten-STAT

'They (for example, the mangoes) are rotten.'

(11a) alıja kwiigolilo

a-liI-j-a ko-igólílv

1SM-IPFV-go-FV LOC.17NP-market

'S/he is going to the market.'

(11b) aziilé kwígolílo

a-o-j-íle kv-igólílo

1SM-PST-go-STAT LOC.17NP-market

'S/he is going to the market.'

7 In Vendler's analysis, both activities and states represent atelicity, that is, they both refer to an event which is not presented as having an endpoint. 
Although the Hodiernal Past and the stative construction (10), or the Imperfective aspect and the stative construction (11), have similar temporal interpretations in English, their difference has to do with both the source of evidence the speaker uses to justify the truth of the proposition expressed, and the speaker's attitude towards the validity of the evidence. This is discussed further in the following section.

\section{EVIDENTIAL STRATEGIES IN NYAMWEZI}

This section is divided into two subsections. Section 5.1 discusses the evidential readings that occur when tense and aspect constructions appear to have the same temporal interpretation in English. Since this study seeks to provide a general description of evidentiality in Nyamwezi, Section 5.2 discusses other strategies of encoding evidentiality.

\subsection{Tense and aspect constructions as evidential strategies}

Nyamwezi, like many other Bantu languages, has many tense and aspect constructions. This language distinguishes four types of past tenses, namely Immediate Past, Hodiernal Past, Pre-hodiernal Past, and Remote Past, and two types of future tenses, namely Hodiernal Future and Post-Hodiernal Future (Kanijo 2012; Maganga \& Schadeberg 1992). As exemplified in (12) below, the dividing point for these tenses is generally between today and before/after today. All examples are given using the tones of the underlying formatives.

(12) Tense constructions

\begin{tabular}{|c|c|c|c|c|c|c|}
\hline & SM & TAM & Root & TAM & $\begin{array}{l}\text { TAM/ } \\
\text { FV }\end{array}$ & Example \\
\hline Immediate Past & $v$ & á & mal & & $\mathrm{a}$ & $\begin{array}{l}\text { w-áá -mal-a } \\
\text { 'S/he finished (just now).' }\end{array}$ \\
\hline Hodiernal Past & v & á & mal & ag & $\mathrm{a}$ & $\begin{array}{l}\text { w-áá-mal-ag-a } \\
\text { 'S/he finished (earlier today).' }\end{array}$ \\
\hline Pre-Hodiernal Past & v & á & mal & & íle & $\begin{array}{l}w \text {-áá-mal-íle } \\
\text { 'S/he finished (yesterday or before).' }\end{array}$ \\
\hline Remote Past & v & $\mathrm{a}$ & mal & & á & $\begin{array}{l}\text { w-aa-mal-á } \\
\text { 'S/he finished (long ago).' }\end{array}$ \\
\hline Hodiernal Future & $\mathrm{a}$ & $\mathrm{kv}$ & mal & & $\mathrm{a}$ & $\begin{array}{l}a-\boldsymbol{k} \boldsymbol{v}-m a-l a \\
\text { 'S/he will finish (today or later).' }\end{array}$ \\
\hline $\begin{array}{l}\text { Post-Hodiernal } \\
\text { Future }\end{array}$ & $\mathrm{a}$ & laa & mal & & é & $\begin{array}{l}\text { a-laa-mal-eé } \\
\text { 'S/he will finish (tomorrow or later).' }\end{array}$ \\
\hline
\end{tabular}

With regard to aspect marking, Nyamwezi expresses five types of grammatical aspect expressed by affixes inflected on the main verb. ${ }^{8}$ As exemplified in (13) below, these aspects express different ways of viewing the internal temporal constituency of a situation. All examples are given using the tones of the underlying constructions.

8 Nyamwezi also has a Persistive aspect, which differs from other grammatical aspects in that it is inflected on the auxiliary verb (see Kanijo 2019a). 
(13) Aspect constructions

\begin{tabular}{|c|c|c|c|c|c|c|}
\hline & SM & TAM & Root & TAM & $\begin{array}{c}\text { TAM/ } \\
\text { FV }\end{array}$ & Example \\
\hline Inceptive & v & yưv & mal & & $\mathrm{a}$ & $\begin{array}{l}w-\boldsymbol{a} a-y v^{\prime}-\text { mal-a } \\
\text { 'S/he is about to finish.' }\end{array}$ \\
\hline Imperfective & $\mathrm{a}$ & liI & mal & & $\mathrm{a}$ & $\begin{array}{l}a-l \text { II-mal-a } \\
\text { 'S/he is finishing.' }\end{array}$ \\
\hline Habitual & $\mathrm{a}$ & $\mathrm{kv}$ & mal & ag & $\mathrm{a}$ & 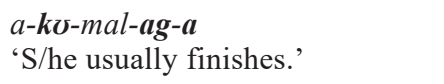 \\
\hline $\begin{array}{l}\text { Past } \\
\text { Habitual }\end{array}$ & v & $\mathrm{a}$ & mal & ag & é & $\begin{array}{l}\text { w-aa-mal-ag-é } \\
\text { 'S/he used to finish.' }\end{array}$ \\
\hline Stative & $\mathrm{a}$ & & mal & & íle & $\begin{array}{l}\text { a-mal-ile } \\
\text { 'S/he is finished (with this task).' }\end{array}$ \\
\hline
\end{tabular}

As shown in (10) and (11), with verbs referred to as inchoatives and directionals in this study, the Hodiernal Past, Imperfective aspect, and stative construction (unlike other tense and aspect constructions) tend to have similar temporal interpretations in Nyamwezi. In this section, I will argue that even though there appears to be some overlap in meaning between these three tense and aspect constructions, the contexts in which these constructions are used can be explained if we incorporate principles of evidentiality.

\subsubsection{The Hodiernal Past and the stative construction}

In non-inchoative verbs, the Hodiernal Past construction $\left(-a^{\prime}-\ldots-a g-\ldots-a\right)$ is typically used to denote events or situations that occurred earlier on the same day or night, as shown in (14a). In contrast, the stative construction $(-\varnothing-\ldots-$-ile) is generally infelicitous with non-inchoative verbs, as shown in (14b).

\begin{tabular}{|c|c|c|c|c|}
\hline$(14 a)$ & $\begin{array}{l}\text { leeloó diiyú, } \\
\text { leelóo diíyu } \\
\text { today morning }\end{array}$ & $\begin{array}{l}\text { kaaná } \\
\text { ka-ána } \\
\text { 12NP-child }\end{array}$ & $\begin{array}{l}\text { káálumágwa } \\
\text { ká-á-lúm-ag-w-a } \\
\text { 12SM-PST-bite-HOD PST-PASS-FV }\end{array}$ & $\begin{array}{l}\text { mayokí } \\
\text { ma-yókI } \\
\text { 6NP-bee }\end{array}$ \\
\hline
\end{tabular}

'This morning, a small child was stung by the bees.'

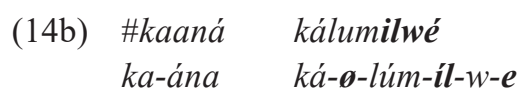

12NP-child 12SM-PST-bite-STAT-PASS-STAT

Intended: 'The small child is stung by bees.'

The stative construction is generally restricted to inchoative verbs. In these verbs, the construction indicates a present state reading, as exemplified in (15) below.

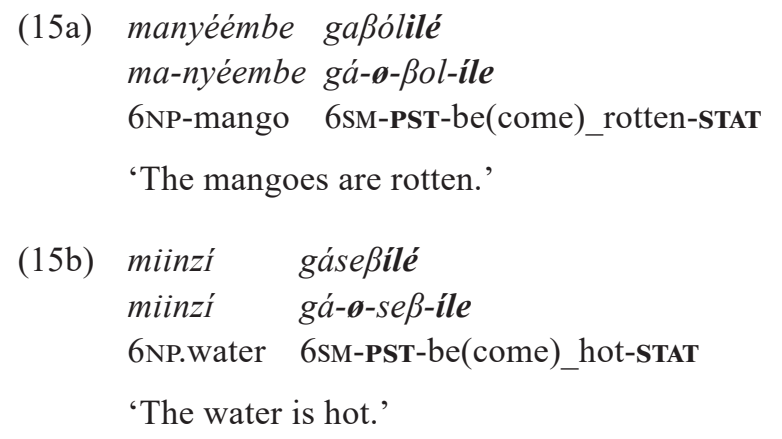


In inchoative verbs (unlike non-inchoatives), the Hodiernal Past $(-\dot{a}-\ldots-a g-\ldots-a)$ carries an implicature of a continued state, that is, it describes an event which is completed but its results can still be seen in the present time (16). In this regard, the Hodiernal Past is similar to the stative construction $(-f-\ldots-$-ile $)$ : both indicate a present state reading. In the Hodiernal Past, the present state is a result of a past/prior event.

(16a) manyéémbe gaaßólaga

ma-nyéembe gá-á-ßol-ag-a

6NP-mango 6SM-PST-be(come)_rotten-HOD_PST-FV

'The mangoes are rotten (lit. have become rotten).'

(16b) miinzí gaaséßaga

miinzí gá-á-se $\beta$-ag-a

6NP.water 6SM-PST-be(come)_hot-HOD_PST-FV

'The water is hot (lit. has become hot).'

Although both the Hodiernal Past and the stative construction in (15) and (16) above have the same temporal interpretation (in English), this does not mean that they can be used interchangeably in every context. The stative construction is acceptable in a context where the speaker is less certain and has no direct evidence for his/her statement. This is exemplified in (17) below, where the use of the stative construction suggests that the speaker is just speculating that the mangoes are rotten. ${ }^{9}$ In contrast, the Hodiernal Past is used when the speaker is certain about the truth of the statement expressed. This is exemplified in (18) below.

Context: The speaker looks at the mangoes in a basket in front of her/him.

(17) manyéémbe gaßólilé

ma-nyéembe gá-o- $\beta$ ol-íle

NP6-mango SM6-PST-be(come)_rotten-STAT

'The mangoes are rotten (I suspect).'

Context: The speaker suspects that the mangoes are rotten from touching them, because they are softer than usual (inference evidence), or because s/he was told so by someone else (reported evidence).

(18) manyéémbe gaaßólaga ma-nyéembe gá-á- $\beta$ ol-ag-a NP6-mango SM6-PST-be(come)_rotten-HOD_PST-FV

'The mangoes are rotten (that is, have become rotten) (I'm sure).'

In (17) above, the speaker's evidence on the use of the stative construction is based on non-firsthand sources, that is, the evidence is obtained through reasoning (inferred evidence) or someone else's narration (reported evidence). In contrast, the speaker's evidence in the example using the Hodiernal Past can be based on either firsthand or non-firsthand sources, as long as $\mathrm{s} / \mathrm{he}$ is sure of what $\mathrm{s} / \mathrm{he}$ is saying.

9 Gunnink (2018: 371) reports a similar phenomenon in Fwe, where a stative form is used for situations in which the speaker is uncertain about the results of the past event, and the Near Past Perfective for situations in which the speaker is certain about the result state. 
Evidential readings can also be seen in inchoative verbs that indicate a change of position, such as -ikala 'sit/be seated' and -itướndá 'squat'. In these verbs, as shown in (19) and (20) below, both the Hodiernal Past and the stative construction denote present state readings. However, the difference between them depends on whether or not the speaker has a clear view of the person (or thing) referred to in the proposition. If the speaker cannot clearly see the person referred to in the proposition, she would use the stative construction, as in (19) below. The use of the stative construction in this case indicates doubt or disbelief on the speaker's part towards the truth of the proposition expressed. The speaker has some doubt because $\mathrm{s} /$ he does not have a clear view of what $\mathrm{s} / \mathrm{he}$ is looking at. This evidence is based on a non-firsthand source.

Context: The speaker sees someone from a distance, and s/he has some doubt about whether the person is seated or not (non-firsthand evidence).

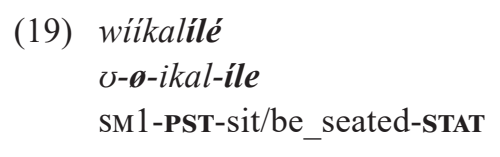

'S/he is seated (I suspect).'

In contrast, if the speaker has a clear view of the person referred to in the proposition, or has been told about it by someone who was very close to the person referred to, s/he would use the Hodiernal Past in the construction (see (20) below). This means that the speaker is sure of what $\mathrm{s} /$ he is talking about; $\mathrm{s} / \mathrm{he}$ has strong evidence about the truth of the proposition expressed. Unlike the stative construction, the evidence for the Hodiernal Past can be based on either firsthand or non-firsthand sources.

Context: The speaker clearly sees that the person is seated (firsthand evidence), or s/he was told about it by someone else (non-firsthand evidence).

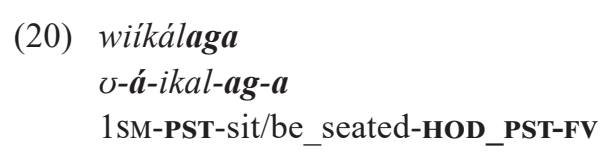

' $\mathrm{S} / \mathrm{he}$ is seated (lit. has sat and is still seated) (I'm sure).'

From the above examples, we have seen that in contexts where the meanings of the Hodiernal Past and the stative construction overlap, the difference has to do with the speaker's confidence in the proposition expressed and in his/her source of evidence. That is, the use of the Hodiernal Past indicates that the speaker is certain, while the use of the stative construction indicates uncertainty on the speaker's part. The justification for this comes from the way these tenses or aspects interact with gitt 'as (if), like'. This word is used in the construction if the speaker is uncertain about the truth of the assertion (or when making a statement about probability). This word generally sounds odd with the Hodiernal Past, as shown in (21), but is fine with the stative construction, as in (22).

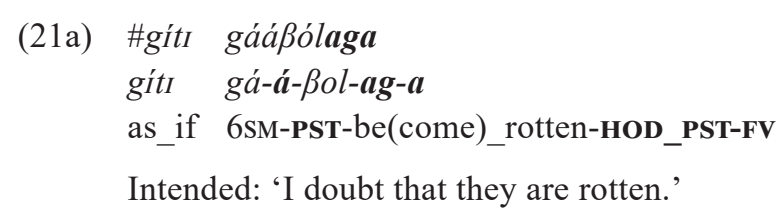


(21b) \#gítı wiíkálaga

gítı $\quad$-á-ikal-ag-a

as_if 1sM-PST-sit/be_seated-HOD_PST-FV

Intended: 'I doubt that $\mathrm{s} /$ he is seated.'

(22a) gítı gaßólilé

gítı gá-o- $\beta$ ol-íle

as_if 6SM-PST-be(come)_rotten-STAT

'I doubt that they are rotten.'

(22b) gítI wiikalílé

gítı v-o-ikal-íle

as_if 1SM-PST-sit/be_seated-STAT

'I doubt that s/he is seated.'

There is a close connection between the meaning of gitt 'as (if), like' and the stative construction, as they both indicate that the speaker's attitude toward the proposition expressed is uncertain. Thus, their co-occurrence is possible. Since the Hodiernal Past is employed when the speaker is certain about the factuality (truth) of assertion, it sounds odd with gitt and they therefore do not co-occur in the language.

\subsubsection{The Imperfective aspect and the stative construction}

In non-inchoative verbs, the Imperfective aspect in Nyamwezi is typically used to denote an event which is in progress at or around the reference time, as shown in (23) below.

$\begin{array}{ll}\text { (23a) alızugá } & \text { mátoßoólwa } \\ \text { a-lII-zúg-a } & \text { ma-toßólwa } \\ \text { 1SM-IPFV-cook-FV } & \text { 6NP-dried_boiled_sweet_potatoes }\end{array}$

'S/he is (right now) cooking dried boiled sweet potatoes.'

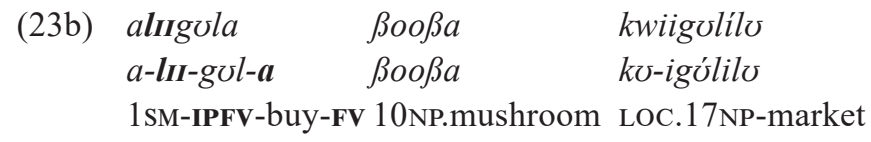

'S/he is buying mushrooms at the market.'

In contrast, the stative construction, as we have seen in Section 5.1.1, is infelicitous with non-inchoative verbs. This grammatical aspect occurs with inchoative verbs to indicate a present state reading (see example (15) above). Although the stative construction does not usually occur with non-inchoative verbs, there is a handful of these verbs which can occur with this construction. These verbs are referred to as directionals in this study, and they include -ja 'go (somewhere)', -peela 'run (to something)', -shooka 'return (reverse, move backwards)', and -iza 'come (back towards a particular point)'. In these verbs, the stative construction denotes a progressive-like reading, ${ }^{10}$ as exemplified in (24) below. This reading is similar to that denoted by the Imperfective aspect, illustrated in (25).

10 Crane (2013: 175) and Gunnink (2018: 373) also noted that in Totela and Fwe, respectively, the stative construction (in some contexts) may occur with non-inchoative verbs to denote a progressive reading. 


$$
\begin{aligned}
& \text { (24a) aziile kwígolílo } \\
& \text { a-o-j-íle kv-igólilv } \\
& \text { 1SM-PST-go-STAT LOC.17NP-market }
\end{aligned}
$$

'S/he is going to the market.'

$$
\begin{aligned}
& \text { (24b) apeelilé kơjaa komadớka } \\
& \text { a-o-j-íle kó-j-a kv-ma-dớka } \\
& \text { 1SM-PST-go-STAT INF. 15NP-go-FV LOC. 17NP-6NP-shop } \\
& \text { (25a) alıja kwiigolílv } \\
& \text { a-lı-j-a ko-igólilo } \\
& \text { 1SM-IPFV-go-FV LOC.17NP-market } \\
& \text { (25b) alıpeela kơjaa komadớka } \\
& \text { a-liI-j-a kó-j-a ko-ma-dớka } \\
& \text { 1SM-IPFV-go-FV INF. } 15 \mathrm{NP}-\text { go LOC.17NP-6NP-shop }
\end{aligned}
$$

'S/he is running (going) towards the shops.'

Even though the stative construction and the Imperfective aspect seem to have similar translations in English, they cannot be used interchangeably in every context. The stative construction is appropriate if the speaker is referring to an event which is ongoing, but which $\mathrm{s} / \mathrm{he}$ does not directly see or hear, as illustrated contextually in (26a) below. Lolagáa! 'Look!' and naliígwá 'I hear (that)' indicate that the source of the information is firsthand; thus, as illustrated in (26b-c) below, the stative construction is infelicitous with these constructions.
(26a) aziilé
a-o-j-íle
kớkázimá
tála
1SM-PST-go-STAT INF.15NP-IT-extinguish-FV 9NP.lamp
'S/he is going to switch off the light.'
Context: The speaker is outside the house and cannot see (or hear the footsteps of) the person who went inside to switch off the light.
(26b) \#lolagáa! aziilé kókázimá tála

lol-ag-a a-o-j-íle ko-ka-zím-á tála
look-IMP-FV 1SM-PST-go-STAT INF.15NP-IT-extinguish-FV 9NP.lamp
Intended: 'Look! S/he is going to switch off the light.'
(26c) \#naliigw' ớó-jon' iihah' aapeelilé
ná-lII-ígw-a o-joni ihaaha a-o-peel-íle
1SM-IPFV-hear-FV AUP-John now 1SM-PST-run-STAT
Intended: 'I hear John running.'

In contrast, the Imperfective is used in contexts where the speaker has some evidence that the event is actually taking place. As in the Hodiernal Past, the evidence for the use of the Imperfective aspect can be based either on firsthand sources, such as visual and auditory evidence, exemplified in (27a) and (27b), respectively, or on non-firsthand sources, exemplified in (27c). 

(27a) lolagáa!
alıja
kokazimá
tála
lol-ag-a
$a-\operatorname{lII}-j-a$
kv-ka-zim-a
tála
look-IMP-FV
1SM-IPFV-go-FV
NF.15NP-IT-ex

'Look! S/he is going to switch off the light.'

(27b)
naliígw'
úú-jon
iihah
aalıpeela

$n a ́-l_{I I-} \lg w-a$

U-joni

ihaaha

a-liI-peel-a

1SM-IPFV-hear-FV AUP-John now

1SM-IPFV-run-FV

Intended: 'I hear John running.'

$(27 \mathrm{c})$

$\begin{array}{lll}\text { alıjja } & \text { kokazimá } & \text { tála } \\ \text { a-lII-j-a } & k v-k a-z i m-a ́ & \text { tála } \\ \text { 1SM-IPFV-go-FV } & \text { INF.15NP-IT-extinguish-FV } & \text { 9NP.lamp }\end{array}$

'S/he is going to switch off the light.' (The speaker didn't see her/him; s/he was told by someone else.)

Generally, in the above examples, the stative construction refers to what is happening based on indirect sources of information (see example (26)), while Imperfective aspect is based on both direct and indirect sources (see example (27)) (cf. Roth 2018). Furthermore, the use of the stative construction in (26), as we saw in (19), indicates that the speaker is less certain about the occurrence of the event. In contrast, the use of the Imperfective aspect in (27), like that of the Hodiernal Past (see example (20)), indicates the opposite pattern. In this case, the speaker is certain, usually because s/he has robust evidence for the occurrence of the event.

The word gitt 'as (if), like', which is used as evidence for the distinction between the Hodiernal Past and the stative construction (see examples (21) and (22)), can also be used here as a piece of evidence for the distinction between the Imperfective and the stative construction. As shown in (28a) below, the Imperfective sounds odd with git t because the Imperfective indicates the factuality of the assertion. On the other hand, git in (28b) sounds fine with the stative construction because both indicate probability.
(28a) \#gítı alıja kokazimá tála
gítı a-liI-j-a ko-ka-zím-a tála
as_if 1SM-IPFV-go-FV INF.15NP-IT-extinguish-FV 9NP.lamp
Intended: 'I doubt that $\mathrm{s} /$ he is going to switch off the light.'
(28b) gítı aziilé kưkázimá tála
gítı a-o-j-íle ko-ka-zím-á tála
as_if 1SM-PST-go-STAT INF.15NP-IT-extinguish-FV 9NP.lamp
'I doubt that $\mathrm{s} /$ he is going to switch off the light.'

\subsection{Lexical means of indicating evidentiality}

Lexical means of indicating evidentiality are a common strategy, especially in languages which lack grammatical evidentials, such as many African languages (see Botne 1997; Dimmendaal 2001; Storch 2018 for more discussion). These languages differ from one another based on which types of lexical items or particles play this role. Many languages use verbs such as 'say', 'know', and 'hear', while others use demonstratives, prepositions, and conjunctions. There 
are a few languages in which evidentiality is expressed by special sentential particles (such as ámbu and ampú in Lega; see Botne 1997; 2003a). In Nyamwezi, evidentiality can also be expressed periphrastically through verbs of saying, such as -wíla 'tell (someone)' and verbs of perception such as -igwá 'hear'. These verbs denote both the source of information (or knowledge) expressed in a proposition and the speaker's attitude about the degree of confidence s/he has in the reliability of that information. Both verbs, -wíla 'tell (someone)' and -igwá 'hear', indicate that the information expressed is based on the authority of another person, that is, on a verbal report (as shown in (29a)) or a hearsay report (rumour) (as in (29b)). Both verbs can thus be said to exemplify the REPORTED evidential.

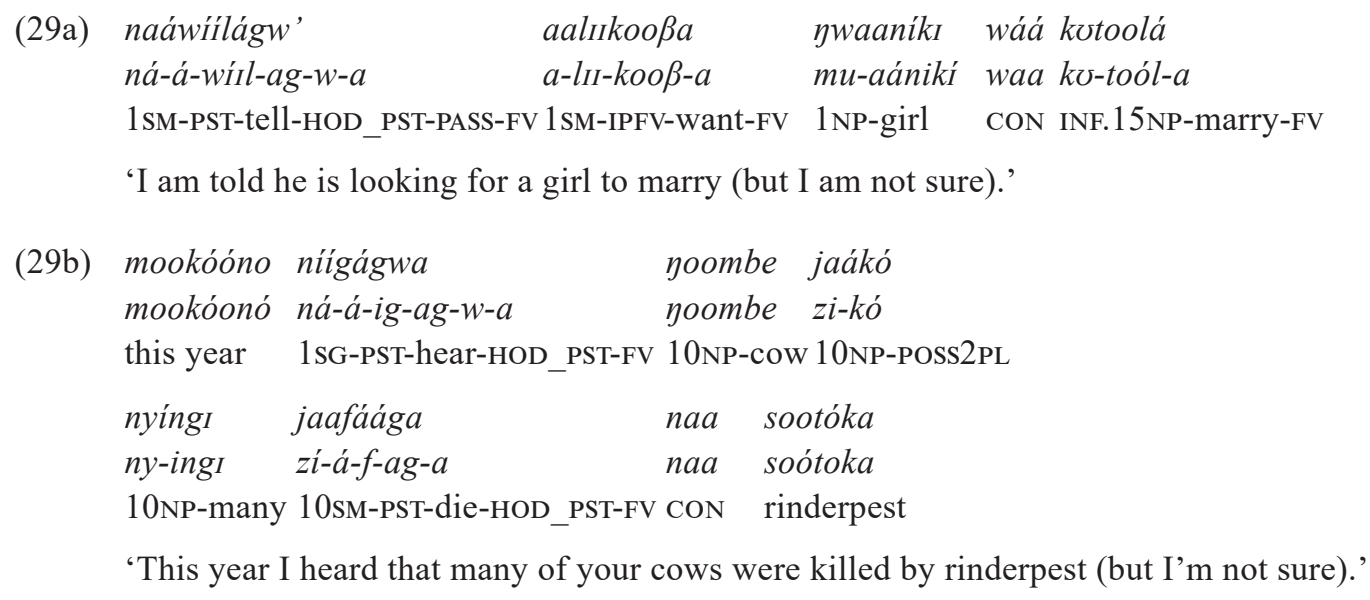

Apart from the two verbs above, epistemic expressions ${ }^{11}$ such as hámó (interpreted as 'maybe, possibly, perhaps' in English) and shíníshi' ${ }^{12}$ (interpreted as '(I) guess') can also be used to indicate doubt as to the truth or reliability of what is reported by the speaker (see example (30) below).
(30a) hámó wáajága
kvkadubvla
yhalaanga.
hámó $\quad \mho-a ́-j-a g-a$
$k v-k a-d u b \sigma l-a$
yhalaanga
maybe 1SM-PST-go-HOD_PST-FV INF.15NP-IT-uproot-FV 9NP.peanuts
'S/he probably went to uproot the peanuts.'
Context: The speaker sees footprints coming to her/his farm.
(30b)
shiíníshí waalaálága
mkaayá
ákaziíle
koshúule
shiÍnıíshí v-á-láal-ag-a
mu-kaáya
a-ká-z-íle
ko-shuule
(I) guess 1SM-PST-sleep-HOD_PST-FV LOC.18NP-homestead 1SM-NEG-go-PFV LOC.17NP-school
'I guess s/he is sleeping in her/his room; s/he didn't go to school (and I don't like it).'
Context: the speaker saw her/his school uniform still hanging outside to dry since it was washed yesterday.

\footnotetext{
11 These expressions, as observed in Maganga and Schadeberg (1992: 139), do not belong to the major word classes in Nyamwezi. They usually function as interjections or exclamations.

12 Shíníshí is an invariable word in Nyamwezi, which can be translated into English as '(I) guess'. It is used when the speaker guesses that an event has taken place or someone has done something which the speaker does not like or did not expect. The speaker's guess is based on things that are found in the context that necessitate the occurrence of the event.
} 
At first glance, one may assume that the particles hámó and shíniÍshí exemplified above have only an epistemic interpretation. That is, they are only used to help the speaker to indicate his/her degree of confidence towards the factuality of the assertion. However, while fulfilling this role, they also saliently indicate that the source of the proposition expressed is based on inferences (conjectures). The footprints in example (30a) are used as a means of knowing that someone went to the farm, while in example (30b), seeing the school uniform hung up on a school day is a means of knowing that someone did not go to school. Since the speaker (in these two examples) based his/her evidence for understanding the situation on tangible evidence of something else, or on experience about a particular phenomenon, then these examples indicate INFERRED (non-firsthand) evidentials.

\section{CONCLUSION}

This paper has aimed to identify strategies for encoding evidentiality in Nyamwezi. The analysis has shown that there are two ways of encoding evidentiality in this language: firstly, through tense and aspect constructions, and secondly through lexical verbs and epistemic expressions. With regard to the first strategy, the paper has discussed three tense and aspect constructions - the Hodiernal Past, Imperfective aspect, and the stative construction - and has shown that in contexts where the interpretations of these tenses or aspects overlap, the difference between them is based on the types (sources) of evidence the speaker has at hand as evidence for the factuality of the assertions. That is, the Hodiernal Past and Imperfective aspect are used if the speaker has evidence to support the proposition asserted, and believes that her/his evidence is robust. The stative construction, on the other hand, is used if the speaker's evidence for the proposition asserted is based on inferences (conjectures/speculations). These findings further confirm Aikhenvald's (2003: 20) proposition that, in languages without a grammatical evidential, "typically a perfect or perfect-like tense carries an inferential or non-eyewitness specification". In addition to tense and aspect constructions, the second strategy for encoding evidentiality in Nyamwezi is through verbs of saying (-wíla 'tell (someone)'), verbs of perception (-igwá 'hear'), and epistemic expressions hámó and shíníshí. In these strategies, the speaker bases her/his evidence about the assertion either on rumours (hearsay) or on her/his experience about a particular phenomenon. It is my hope that the results indicated in this paper will motivate other researchers of tense, aspect, and epistemic modality in African languages to investigate how these categories can be used to express evidential meanings.

\begin{tabular}{|c|c|c|c|}
\hline \multicolumn{4}{|c|}{ Numbers refer to person (first 1 , second 2 , third 3 ) or to noun (class) prefixes. } \\
\hline$\varnothing$ & zero/null & HOD_ & $\Gamma$ hodiernal past \\
\hline , & liaison & INF & infinitive \\
\hline \# & infelicitous & IMP & imperative \\
\hline ADV & adverb & IPFV & imperfective aspect \\
\hline AUP & augment & IT & itive \\
\hline CON & connexive & LOC & locative \\
\hline DAT & dative & NEG & negative \\
\hline FIRSTH & firsthand & NOM & nominative \\
\hline FOC & focus & $\mathrm{NP}$ & noun (class) prefix \\
\hline FV & final vowel & OM & object marker \\
\hline GEN & genitive & ov & object version \\
\hline
\end{tabular}




$\begin{array}{llll}\text { PASS } & \text { passive } & \text { SM } & \text { subject marker } \\ \text { PERF } & \text { perfect } & \text { SG } & \text { singular } \\ \text { PFV } & \text { perfective } & \text { STAT } & \text { stative construction } \\ \text { PL } & \text { plural } & \text { TAM } & \text { tense, aspect, mood } \\ \text { POSS } & \text { possessive } & \text { TS } & \text { tense } \\ \text { PST } & \text { past } & & \end{array}$

\section{REFERENCES}

Aikhenvald, Alexandra Y. 2003. Evidentiality in Typological Perspective. In: A.Y. Aikhenvald \& R.M.W Dixon (eds), Studies in Evidentiality: 1-32. Amsterdam: John Benjamins.

Aikhenvald, Alexandra Y. 2004. Evidentiality. Oxford: OUP.

Botne, Robert 1997. Evidentiality and Epistemic Modality in Lega. Studies in Language 21: 509-532.

Botne, Robert 2003a. Lega (Beya dialect). In: D. Nurse \& G. Philippson (eds), The Bantu Languages: $442-449$. NY: Routledge.

Botne, Robert 2003b. To Die Across Languages: Toward a Typology of Achievement Verbs. Linguistic Typology 7(2): 233-278.

Botne, Robert \& Tiffany L. Kershner 2000. Time, Tense and the Perfect in Zulu. Afrika und Übersee 83: 161-180.

Chafe, Wallace 1986. Evidentiality in English Conversation and Academic Writing. In: W. ChAFE \& J. Nichols (eds): 261-272.

Chafe, Wallace \& Johanna Nichols 1986. Evidentiality: The Linguistic Coding of Epistemology. Norwood, NJ: Ablex Publishing.

Comrie, Bernard 1976. Aspect: An Introduction to the Study of Verbal Aspect and Related Problems, II. Cambridge: CUP.

Crane, Thera Marie 2011. Beyond Time: Temporal and Extra-Temporal Functions of Tense and Aspect Marking in Totela, a Bantu Language of Zambia. PhD dissertation, University of California.

CrAne, Thera Marie 2012. -ile and the Pragmatic Pathways of the Resultative in Bantu Botatwe. Africana Linguistica 18: 41-96.

CRANe, Thera Marie 2013. Resultatives, Progressives, Statives, and Relevance: The Temporal Pragmatics of the -ite Suffix in Totela. Lingua 133: 164-188.

Crane, Thera Marie \& Axel Fleisch 2019. Towards a Fieldwork Methodology for Eliciting Distinctions in Lexical Aspect in Bantu. In: L. Aunio \& A. Fleisch (eds), Lingustic Diversity Research Among Speakers of isiNdebele and Sendebele in South Africa (Studia Orientalia 120). Helsinki: Finnish Oriental Society.

Crane, Thera Marie, Larry M. Hyman \& Simon Nsielanga Tukumu 2011. A Grammar of Nzadi: A Language of Democratic Republic of Congo. Berkeley: UC Press.

DimmendaAL, Gerrit J. 2001. Logophoric Marking and Represented Speech in African Languages as Evidential Hedging Strategies. Australian Journal of Linguistics 21: 131-157.

Dowty, David R. 1979. Word Meaning and Montague Grammar: The Semantics of Verbs and Times in Generative Semantics and in Montague's PTQ. Dordrecht: D. Reidel.

Gunnink, Hilde 2018. A Grammar of Fwe: A Bantu Language of Zambia and Namibia. PhD dissertation, Ghent University.

Guthrie, Malcolm 1967-1971. Comparative Bantu: An Introduction to the Comparative Linguistics and Prehistory of the Bantu Languages, I-IV. London: Gregg International.

de HaAn, Ferdinand 2013. Semantic Distinctions of Evidentiality. In: M.S. Dryer \& M. HaSPelmath (eds), The World Atlas of Language Structures Online. Leipzig: Max Planck Institute for Evolutionary Anthropology. Available at <wals.info/chapter/77>, accessed 4 June 2018.

Hewit, B. George 1995. Georgian: A Structural Reference Grammar. Amsterdam: John Benjamins.

KaniJo, Ponsiano Sawaka 2012. Formatives of Tense and Aspect in the Verbal Construction of Kinyamweezi. MA dissertation, University of Dar es Salaam. 
KaniJo, Ponsiano Sawaka 2019a. Aspectual Classes of Verbs in Nyamwezi. PhD dissertation, University of Gothenburg.

Kanijo, Ponsiano Sawaka 2019b. The Interactions of -ø-...-ile with Aspectual Classes in Nyamwezi. In: S. Lotven, S. Bongiovanni, P. Weirich, R. Botne \& S.G. Obeng (eds), Selected Papers from the 48th Annual Conference on African Linguistics: 281-308. Berlin: Language Science Press.

LeIss, Elisabeth 2012. Epistemicity, Evidentiality and Theory of Mind (ToM). In: W. Abraham \& E. Leiss (eds), Modality and Theory of Mind Elements Across Languages: 39-65. Berlin: De Gruyter Mouton.

Maganga, Clement \& Thilo C. Schadeberg 1992. Kinyamwezi: Grammar, Texts, Vocabulary. Cologne: Rüdiger Köppe.

Miller, Cynthia L. \& Leoma G. Gilley 2007. Evidentiality and Mirativity in Shilluk. In: R. Mechthild \& D. PAYNe (eds), Advances in Nilo-Saharan Linguistics: Proceedings of the 8th International Nilo-Saharan Linguistics Colloquium: 191-206. Cologne: Rüdiger Köppe.

NurSE, Derek 2008. Tense and Aspect in Bantu. NY: OUP.

Roth, Tim 2018. Aspect in Ikoma and Ngoreme: A Comparison and Analysis of Two Western Serengeti Bantu Languages. PhD dissertation, University of Helsinki.

Rugemalira, Josephat M., Henry Muzale, David Massamba, Kulikoyela Kahigi, Azaveli Lwaitama, Abel Yemwaka Mreta \& Yared Kinore (eds) 2009. Atlasi ya lugha za Tanzania (Language Atlas of Tanzania). Dar es Salaam: Chuo Kikuu cha Dar es Salaam.

Storch, Anne 2006. Aspect and Evidentiality in Luwo. In: A. Abu-Manga, L.G. Gilley \& A. Storch (eds), Insights into Nilo-Saharan Language, History, and Culture: Proceedings of the 9th Nilo-Saharan Linguistics Colloquium, Khartoum 2004: 393-402. Cologne: Rüdiger Köppe.

Storch, Anne 2018. Evidentiality and the Expression of Knowledge: An African Perspective In: A.Y. AikHENVALD (ed.), The Oxford Handbook of Evidentiality: 611-628. Oxford: OUP.

Vendler, Zeno 1967. Linguistics in Philosophy. Ithaca: Cornell University Press.

WiLlett, Thomas 1988. A Cross-Linguistic Survey of the Grammaticization of Evidentiality. Studies in Language 12(1): 51-97. 